\title{
Effect of Weeding Frequency on Weed Density, Intensity, Relative Yield Loss and Yield of Food Barley (Hordeom vulgare L.) Variety at Amuru District, Western Oromia
}

\author{
Dessalegn Ayana ${ }^{1, ~ *, ~ H a b t a m u ~ A s h a g r e ², ~ I b r a h i m ~ H a m z a ~}{ }^{3}$ \\ ${ }^{1}$ Department of Plant Science, College of Agriculture and Natural Sciences, Assosa University, Assosa, Ethiopia \\ ${ }^{2}$ Department of Plant Sciences, College of Agriculture and Veterinary Sciences, Ambo University, Ambo, Ethiopia \\ ${ }^{3}$ School of Agriculture and Agricultural Technology, Federal University of Technology, Minna, Nigeria
}

\section{Email address:}

ayanadessalegn074@gmail.com (D. Ayana)

${ }^{*}$ Corresponding author

\section{To cite this article:}

Dessalegn Ayana, Habtamu Ashagre, Ibrahim Hamza. Effect of Weeding Frequency on Weed Density, Intensity, Relative Yield Loss and Yield of Food Barley (Hordeom vulgare L.) Variety at Amuru District, Western Oromia. American Journal of Plant Biology.

Vol. x, No. x, 2021, pp. x-x. doi: 10.11648/j.ajpb.20210602.11

Received: February 17, 2021; Accepted: March 24, 2021; Published: May 14, 2021

\begin{abstract}
The productivity food barley is constrained by the competition of weed and agronomic practices. An experiment was conducted to evaluate the effect of weeding frequency on Relative Weed Density, Weed intensity, Relative yield loss and Yield of Food barley varieties at Amuru District of Horo Guduru Wollega Zone of Oromia National Regional State in 2016 main cropping season. The experiment was laid down in a Randomized Complete Block Design (RCBD) with three replications. The treatments were factorial combination of four weeding frequencies (weedy check, one time weeding, two times weeding and three times weeding) and five food barley varieties (HB-1307, CROSS 41/98, GOBE, EH1493 and Local). The major weed species identified in the study area were Setaria pumila with relative density (31.74\%), population density ( 84 plants $\mathrm{m}^{-2}$ ) and an intensity of 2.1; Snowdenia polystachya with relative density (16.6\%), population density ( 44) with an intensity of 1.1; and Polygonum spp with relative density (10.57\%), population density (28) and an intensity of 0.95 . While others weed species constituted about $27.17 \%$ of a total weed population with a density of 72 plants $\mathrm{m}^{-2}$. Weeding frequency and varieties significantly affected biological and grain yields, and relative yield loss of food barley. Three times weeded treatment gave significantly higher grain $\left(1422 \mathrm{kgha}^{-1}\right)$ and biological $\left(3877.78 \mathrm{kgha}^{-1}\right)$ yields. Moreover, HB-1307 variety gave significantly higher grain $\left(1292 \mathrm{kgha}^{-1}\right)$ and biological $\left(3513.9 \mathrm{kgha}^{-1}\right)$ yields. Therefore, three times weeding with HB-1307 variety is recommended to increase the production and productivity of food barley in the study area.
\end{abstract}

Keywords: Weeding Frequency, Food Barley, Yield Loss and Yield

\section{Introduction}

Barley is one of the commonly grown food security crops in higher altitude areas of Ethiopia. The total number of households cultivating barley at national level is estimated to be 4,095273. Particularly, in Oromia Region of Horo Guduru Wellega Zone the total number of households cultivating barley is estimated to be 32,305 . Similarly, the total number of households cultivating barley in Amuru district is estimated to be 6852 , while the total number of household was estimated to be 13,750 and the total area coverage estimated to be 4234 ha with productivity of 1.3 tha 1 [1].
Weeds are naturally selected in disturbed agricultural ecosystems [2]. They are different from other pests that pose problems in crop production because the presence of weeds is constant, while out breaks of insects and pathogenic diseases are irregular [3]. Weeds were found to be very competitive and harmful to the crop. Takele reported that reduction in the number of fertile tillers per plant and biomass yield due to weed competition were mainly responsible for the crop yield loss [4].

Barley is a plant that is very sensitive to weed competition and suffers the greatest reduction through competition at its third to sixth leaf stage [5]. This is approximately between 
two and four weeks after emergence. Weeds emerging after this time have less competitive effect, but may interfere with the harvest and act as a subsequent source of infestation of the fields. Weeds also can play a significant role in harboring insect, serving as alternative hosts for some diseases and adding to the cost of production. Hence, identifying the type of weeds grown, and determining the intensity and yield losses as a result of weed competition have a paramount significance in the management of weeds in the study area. Hence, the objective of this paper was to evaluate the effect of weeding frequency on Relative weed density, Weed intensity, Relative yield loss and Yield of Food barley varieties in the study area.

\section{Materials and Methods}

\subsection{Description of the Study Area}

The experiment was conducted at Amuru District during main rainy season of 2016. It is located in Amuru District which is found in the Eastern part of Horo Guduru Wellega Zone of Oromia National Regional State, and $387 \mathrm{~km}$ from Addis Ababa. According to Oromia Sustainable Land Management program (SLMP) the study area extended from $36^{\circ}$ to $37^{\circ}$ East longitude to $9^{\circ}$ to $10^{\circ}$ North latitude. More than $75 \%$ of the area falls within altitude range of greater than $2300 \mathrm{~m}$ a. s. 1. The rain fall occur only in a single season starting in May and ending in October. The mean annual temperature varies between $15^{\circ} \mathrm{C}$ and $27^{\circ} \mathrm{C}$. The soil of the experimental site was deep alluvial with a sub soil stratified with loam, clay loam and dominated by loam [6].

\subsection{Experimental Materials and Design}

A total of five varieties, four improved cultivars and one local variety were used for the study as experimental material. Five barley varieties (HB-1407, CROSS41/98, EH1493, GOBE, and LOCAL) and four weeding frequencies (unweeded or weedy check, one time weeding (20 DAS), two times weeding (20 and 40 DAS) and three time weeded (20, 40 and 60 DAS) were factorially combined to make a total of 20 treatments. Randomize Complete Block Design (RCBD) in factorial arrangement was adopted in three replications. The plot size used was $2 \mathrm{~m} \times 3 \mathrm{~m}$ with spacing between plots of $0.5 \mathrm{~m}$ and $0.75 \mathrm{~m}$ between blocks. Thus, spacing between rows were $20 \mathrm{~cm}$ using $85 \mathrm{~kg} \mathrm{ha}^{-1}$ seed rate for each treatment, and seven inner rows were considered as a net plot. The outer most rows on both side of each plot were considered as a border and the treatments were randomly assigned.

\subsection{Experimental Field Management}

Land preparation was done three times from May up to mid-June 2016 by using Oxen plough. Planting was done on 29 June 2016 by placing the seeds in hand made furrows. Full dose of phosphate fertilizer in the form of DAP at the rate of $26 \mathrm{~kg} \mathrm{ha}^{-1}$ was applied equally to all plots at the depth of $2 \mathrm{~cm}$ below seeds at time of sowing. While the recommended rate of $60 \mathrm{~kg} \mathrm{ha}^{-1}$ in the form of Urea was applied in split form.

Half of the Nitrogen fertilizer was applied at time of sowing and the remaining half fertilizer was applied at tillering stage of barley to all treatment uniformly. Weeds were managed by hand as per treatment and other agronomic practices were applied uniformly to all plots following the recommended practices for the crop.

\subsection{Data Collection and Measurements}

Weed flora identification: Weeds were identified and recorded using color manuals of weed identification [7].

Weed population: weed populations were counted at 18 days after planting. The population count was taken with the help of $0.25 \mathrm{~m} \times 0.25 \mathrm{~m}$ quadrate thrown randomly at two places in each plot and was converted to population density per $\mathrm{m}^{2}$.

Relative Weed Density (RWD): It was calculated using the following formula as described by [8]:

$$
\text { RWD }(\%)=\frac{\text { No. Particular Weed }}{\text { No. population of Total Weed }} \times 100
$$

Where RWD=Relative weed density, NPW=Population per unit area of a particular weed species, NPTW=Total weed species per unit area

Weed intensity: The ratio of weed population per unit area to equivalent area of crop population was computed as described by [9]:

$$
\text { weed intensity }=\frac{\text { Total number of particular weed }}{\text { Total number of barley crop }}
$$

Grain yield: was measured as a total grain yield from the net plot and converted to hectare base.

Biological yield: was measured by weighing the total sundried aboveground plants parts in kilogram from each plot. Relative yield loss:

Crop yield loss: Yield loss due to weed interferences was calculated based on the maximum yield obtained from a treatment as follows [10]:

$$
\text { Relative yield Loss Index }(R Y L \%)=\frac{M Y \_Y T}{M Y} \times 100
$$

Where, MY=maximum yield from a treatment, $\mathrm{YT}=$ yield from weedy check treatment.

\subsection{Data Analysis}

The collected data was subjected to analysis of variance (ANOVA) according to the Generalized Linear Model (GLM) procedure of SAS Version 9.3 Software and interpretations was made following the procedure of Gomez and Gomez [11]. Mean separations were done using Least Significance Difference (LSD) test at 5\% level of significance. 


\section{Result and Discussion}

\subsection{Weed Types Identification, Relative Density and Intensity}

The major weed species identified in the study area were Setaria pumila $(31.74 \%)$ with a population density of 84 plants per square meter and an intensity of 2.1; Snowdenia polystachya $(16.60 \%)$ with a population density of 44 and an intensity of 1.1, Polygonum spp (10.57\%) with a population density of 28 and an intensity of 0.95 and others weed which constituted about $27.17 \%$ of a total weed population with density of 72 plants per square meter (Table 1). Both broad and grass leaves weed species affect the growth and development of barley in the study area. This was similar with the work of [12] who reported that broad leaved weed $(72 \%)$ and grass $(24 \%)$ dominated from the total weed spectrum, whereas sedges $(4 \%)$ were minor.

Table 1. Weed population, intensity and density in the experimental field during 2016 cropping season of Amuru.

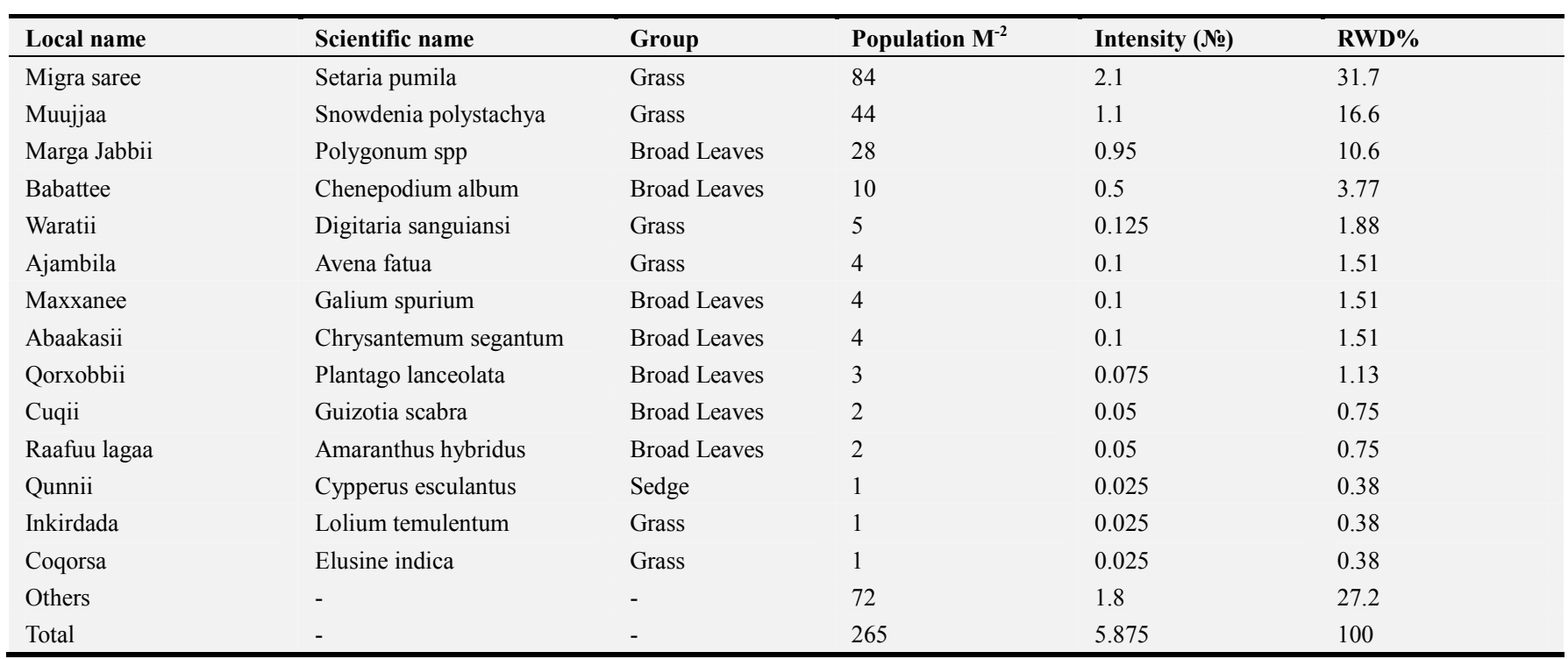

RWD=Relative weed density

\subsection{Grain Yield}

Weeding frequency significantly $(\mathrm{P}<0.05)$ affected grain yield per hectare (Table 2$)$. The highest $\left(1422 \mathrm{~kg} \mathrm{ha}^{-1}\right)$ mean grain yield was obtained from three times weeded while the lowest mean $\left(511 \mathrm{~kg} \mathrm{ha}^{-1}\right)$ obtained from weedy check. The treatments having higher weed frequency resulted in higher grain yield Grain yield increases with increasing weeding frequency.

Grain yield per hectare was found to be affected significantly $(p<0.05)$ by barley varieties. Significantly higher grain yield (1292 $\left.\mathrm{kgha}^{-1}\right)$ and $958 \mathrm{kgha}^{-1}$ were recorded for variety $\mathrm{HB}-1307$ and GOBE, while lower for CROSS 41/98 (764 kg ha $\left.{ }^{-1}\right)$, EH1493 (542 $\left.\mathrm{kgha}^{-1}\right)$ and the Local cultivar $\left(792 \mathrm{~kg} \mathrm{ha}^{-1}\right)$. Local cultivars usually give low yields due to lodging and shattering problem [13]. This result agrees with the investigations of [14] who reported that high yield was characterized by medium plant height and high thousand kernel weight in Ethiopian barley genotypes.

\subsection{Biological Yield}

Main effect of weeding frequency and varieties significantly affect Biological yield of barley at $(\mathrm{P}<0.01)$ and $(\mathrm{P}<0.05)$, respectively (Table 2$)$. Considerably higher $(3878$ $\mathrm{kg} \mathrm{ha}{ }^{-1}$ ) biological yield was obtained from three times weeded but didn't significantly differ from two times weeded (3133 $\left.\mathrm{kg} \mathrm{ha}^{-1}\right)$. The lowest $\left(1500 \mathrm{~kg} \mathrm{ha}^{-1}\right)$ biological yield was obtained from weedy check. These results indicated that weeding at different stages of the crop and weed had great influence on biological yield. The lowest biological yield which was recorded from weedy check was due to competition between crops and weeds for light interception, available nutrients and moisture for both straw and grain accumulation. Mizan [15] reported that increased biological yield of the crop was highly governed by the length of weed free period. Similarly, Shrestha [16] reported that the removal of weeds from crop at earlier time could boost the yield components and yield.

The result of the study also demonstrated that biological yield was influenced by main effect of varieties. Variety HB-1307 produced the largest (3514 $\mathrm{kgha}^{-1}$ ) biological yield, followed by Local (2639 $\left.\mathrm{kg} \mathrm{ha}^{-1}\right)$, GOBE (2486 $\left.\mathrm{kg} \mathrm{ha}^{-1}\right)$, and EH1493 (2431 kg ha-1), while CROSS 41/98 resulted in low biological yield (1364 $\left.\mathrm{kg} \mathrm{ha}^{-1}\right)$. The higher yielding varieties were found to have both greater biomasses. The result agrees with Yetsedaw [17] who reported genotypes variability in biomass yield of barley. 
Table 2. Main effect of Varieties on yield and yield components of Barley as influenced by weeding frequency at Amuru 2016.

\begin{tabular}{|c|c|c|c|}
\hline Treatment & Grain yield $\left(\mathrm{Kg} \mathrm{ha}^{-1}\right)$ & Biological yield $\left(\mathrm{Kg} \mathrm{ha}^{-1}\right)$ & Relative yield loss (\%) \\
\hline \multicolumn{4}{|l|}{ Weeding Frequency } \\
\hline Weedy check & $511.1^{\mathrm{d}}$ & $1499.99^{b}$ & $64.98^{\mathrm{a}}$ \\
\hline One time weeding & $644.44^{\mathrm{c}}$ & $2055.55^{b}$ & $53.16^{\mathrm{ab}}$ \\
\hline Two times weeding & $899.98^{b}$ & $3133.33^{a}$ & $34.33^{\mathrm{b}}$ \\
\hline Three times weeding & $1422.22^{\mathrm{a}}$ & $3877.78^{a}$ & $0^{\mathrm{c}}$ \\
\hline $\operatorname{LDS}(0.05)$ & 172.2 & 754.54 & 19.4 \\
\hline \multicolumn{4}{|l|}{ Varieties } \\
\hline HB-1307 & $1291.98^{\mathrm{a}}$ & $3513.9^{a}$ & $37.17^{\mathrm{ab}}$ \\
\hline CROSS 41/98 & $763.88^{\mathrm{bc}}$ & $2138.89^{b}$ & $44.85^{\mathrm{a}}$ \\
\hline GOBE & $958.33^{\mathrm{ab}}$ & $2486.1^{b}$ & $44.08^{\mathrm{a}}$ \\
\hline EH1493 & $541.55^{\mathrm{c}}$ & $2430.6^{b}$ & $25.02^{\mathrm{b}}$ \\
\hline Local & $791.65^{\mathrm{bc}}$ & $2386.9^{b}$ & $35.28^{\mathrm{ab}}$ \\
\hline $\operatorname{LSD}(0.05)$ & 385.39 & 843.8 & 22.03 \\
\hline $\mathrm{CV}(\%)$ & 26.82 & 30.29 & 28.5 \\
\hline
\end{tabular}

Means in column followed by the same letter are not significantly different at $5 \%$ probability level

Relative Yield Loss: The analysis of the result showed that weeding frequencies and varieties have significant $(\mathrm{P}<0.05)$ effect on relative yield loss (Table 2). The highest relative yield loss was occurred on weedy check (64.98\%), followed by one times weeded $\mathrm{n}(53.16 \%)$ and two times weeded $(34.33 \%)$ treatments. This result agreed with the work of Ologbon and Yusuf [18] among cultural weed control methods, hand weeding and hoeing can reduce weed emergence up to $80 \%$, resulting in a $69 \%$ increase in wheat yield increment. The main effects of varieties showed highly significant $(\mathrm{P}<0.05)$ effect on relative yield loss of barley. Higher relative yield loss was occurred on variety CROSS 41/98 (44.85\%) and GOBE (44.08\%) whereas the lower relative yield loss recorded on EH1493 variety (25.02\%). Therefore, weeding frequency was more limiting factors than variety for food barley production at the test locations.

\section{Conclusion and Recommendation}

Based on the experimental field, more than fourteen weed species infested. Among them Setaria pumila, Snowdenia polystachya, Polygonum spp. and Chenepodium album etc. are the most dominant weed species in the study area. The main effect of weeding frequencies and varieties significantly influenced yield parameters of barley. Three times weeding was increased grain and biological yield, as well as decreased relative yield loss of barley due to weed. Of the four varieties tested in the experiment, the higher biological and grain yields were obtained from HB-1307 genotype of barley. Accordingly, three times weeding frequency at (20,40, and 60 DAS) was found the optimal weeding frequency which gave higher grain yield of barley. Hence, barley producing farmers in the study area can be advised to grow HB-1307 variety with three times weeding frequency to increase barley production and productivity.

\section{References}

[1] Agricultural Transformation Agency (ATA). 2005. Barley production package, May 2005. Finfine Oromia.
[2] Ahmed M. El Naim, Mona A. Eldouma and Abdu E. Abdalla. 2010. Effect of weeding frequencyes and plant density on the vegetative growth characteristic in groundnut (Arachis hypogaeal. L). International Journal of Applied Biology and Pharmaceutical Technology 1 (3): 0976-4550.

[3] Burgos, N. R., R. J. Norman, D. R. Gealy and H. Black. 2006. Competitive $\mathrm{N}$ uptake between rice and weedy rice, Field Crops Research 99: 96-105.

[4] Ceccarelli, S. and S. Grando, 2006. Hordeum vulgare L. [Internet] record from protabase. Brink, M. and Belay G. (Ed). PROTA (Plant resources of Tropical Africa Wageninge Netherlands. http://search.htm.accesed on July 1, 2016.

[5] Central Statistics Agency (CSA). 2015. Agricultural sample survey report on private peasant holdings, meher season 2014/20015 VOLUME I, Addis Abeba, Ethiopia.

[6] Dawit Dalga, J. J Sharma and Tamado Tana. 2014. Growth and Yield of Bread Wheat (Triticum aestivum L.) as Influenced by Row Spacing and Weeding Frequency in Southern Ethiopia. Journal of Agricultural Research, 8 (1): 19-30.

[7] Ekeleme F., Kamara, A. Y., Oikeh, S. O., Chikoye D. and Omoigui, L. O. 2007. Effect of weed competition on upland rice production in north-eastern Nigeria. Africa Rice Center (WARDA); African Crop Science Conference proceedings 8: 61-65.

[8] El-banna, M. N. M. A., EL-Gawad Nassir, M. N. Mohammed and M. A. EL-Azeem Boseely 2011 Evaluation of 16 barley genotypes under calcareous soil conditions in Egypt. Journal of Agricultural Science. 3 (1): 105-121.

[9] Fekadu W. and Skjelvag A. 2002. Soil water requirements and response to fertilization of barley in Northern Ethiopia Doctoral Scientiarum, Norway University.

[10] Gianessi L. and S. Sankula, 2003. The value of herbicides in U.S. crop production, National Centre for food and Agricultural Policy, April 2003 technical report.

[11] Girma Gemedi. 2012. Yield and yield components of barley (Hordeum vulgare L.) Varieties as influenced by sowing date and pesticide application at Holeta, central Ethiopia. Msc. Thesis Haramaya Universsity, Haramaya Ethiopia.

[12] Gomez, K. A. and Gomez A. A. 1984. Statistical procedures for agricultural research. ( $2^{\text {nd }}$ ed.). A Wiley-International Publication John Wiley and Sons, Inc., New York. 
[13] International Center for Agricultural Research in the Dry Areas (ICARDA).2008.www. icarda.org/publications/Donors/Ethiopia/G-Barley.htm. Accessed on February 2, 2017.

[14] Kebede Desta. 2000. Weed control methods used in Ethiopia. Animal powers for weed control, A Resource Book of the Animal Traction Network for Eastern and Southern Africa.

[15] Ologbon O. and Yusuf S. 2012. Economics of weed control practices on rice farms in Obafemi-owode area of ogunstate, Nigeria. Journal of Agricultural and Biological Science, 9: 45-60.
[16] Oromia Sustainable Land Management Program (SLM).2014. Amuru Woreda Multiyear Plan Document for Dero-Welage watershed Management, Oromia BoA assisted by GIZ SLM Oromia.

[17] Takele Negewo, Matias Mekuria \& Temam Hussien. 2006. Competition effects of major weed species at various densities on yield and yield components of barley (Hordeum vulgare L.), Journal of Ethiopia. 10: 53-59.

[18] Tesfaye Amare, Amin Mohammed, and. Mulugeta Negeri. 2015. Effect of weed control methods on weed density and Maize (Zea mays L.) yield in west Shewa Oromia. African Journal of Plant sciences. Vol 9 (1) pp 8-12, January 2015. 